\title{
Molecular analysis of the AGL gene: heterogeneity of mutations in patients with glycogen storage disease type III from Germany, Canada, Afghanistan, Iran, and Turkey
}

\author{
Yoriko Endo · Asako Horinishi · Matthias Vorgerd · Yoshiko Aoyama • \\ Tetsu Ebara - Toshio Murase - Masato Odawara - Teodor Podskarbi · \\ Yoon S. Shin $\cdot$ Minoru Okubo
}

Received: 28 May 2006/ Accepted: 26 July 2006/ Published online: 19 September 2006

(C) The Japan Society of Human Genetics and Springer-Verlag 2006

\begin{abstract}
Glycogen storage disease type III (GSD III) is an autosomal recessive disorder characterized by excessive accumulation of abnormal glycogen in the liver and/or muscles and caused by deficiency in the glycogen debranching enzyme $(A G L)$. Previous studies have revealed that the spectrum of $A G L$ mutations in GSD III patients depends on ethnic grouping. We investigated nine GSD III patients from Germany, Canada, Afghanistan, Iran, and Turkey and identified six novel $A G L$ mutations: one nonsense
\end{abstract}

Electronic Supplementary Material Supplementary material is available in the online version of this article at http://dx.doi.org/ 10.1007/s10038-006-0045- $\mathrm{x}$ and is accessible for authorized users.

Y. Endo $\cdot$ A. Horinishi $\cdot$ Y. Aoyama

T. Ebara $\cdot$ T. Murase $\cdot$ M. Okubo $(\varangle)$

Okinaka Memorial Institute for Medical Research,

2-2-2 Toranomon, Minato-ku, Tokyo 105-8470, Japan

e-mail: QFG00550@nifty.ne.jp

M. Vorgerd

Department of Neurology, Ruhr University Bochum,

Bochum, Germany

M. Odawara

Third Department of Internal Medicine,

Tokyo Medical University, Tokyo, Japan

T. Podskarbi

Molecular Genetics and Metabolism Laboratory,

Munich, Germany

Y. S. Shin

Department of Pediatrics, University of Munich,

Munich, Germany

M. Okubo

Department of Endocrinology and Metabolism,

Toranomon Hospital, Tokyo, Japan
(W255X), three deletions (1019delA, 3202-3203delTA, and 1859-1869del11-bp), and two splicing mutations (IVS7 + 5G > A and IVS21 + 5insA), together with three previously reported ones (R864X, W1327X, and IVS21 + $1 \mathrm{G}>\mathrm{A}$ ). All mutations are predicted to lead to premature termination, which abolishes enzyme activity. Our molecular study on GSD III patients of different ethnic ancestry showed allelic heterogeneity of $A G L$ mutations. This is the first $A G L$ mutation report for German, Canadian, Afghan, Iranian and Turkish populations.

Keywords AGL - Deletion - Glycogen debranching enzyme - Glycogen storage disease type III ·

Haplotype $\cdot$ Insertion · Nonsense mutation ·

Splicing mutation

\section{Introduction}

Glycogen storage disease type III (GSD III; MIM \#232400) is an autosomal recessive inherited disorder caused by deficiency in the glycogen debranching enzyme, a key enzyme in the degradation of glycogen. The enzyme has two independent catalytic activities, oligo-1,4-1,4-glucantransferase (EC 2.4.1.25) and amylo-1,6-glucosidase (EC 3.2.1.33), on a single $160 \mathrm{kDa}$ protein. Both activities and glycogen binding are required for complete function. The glycogen-binding site is assumed to be located in the carboxyl terminal of its protein. In GSD III patients the enzyme's activities are virtually absent in affected organs. Deficiency in the enzyme results in an excessive accumulation of abnormal glycogen. Typical clinical manifestations are hepatomegaly, pro- 
gressive myopathy, cardiomyopathy, and fasting hypoglycemia (Chen 2001). Most patients have both liver and muscle involvement (GSD IIIa), but approximately $15 \%$ of patients have solely liver involvement without any muscular manifestations (GSD IIIb). These subtypes have been explained by differences in tissue expression of the deficient enzyme.

The human AGL gene $(A G L)$ has been isolated and shown to be $85 \mathrm{~kb}$ in length and composed of 35 exons, encoding a $7.0 \mathrm{~kb}$ mRNA (Bao et al. 1996). Liver glycogen debranching enzyme, a predominant form, is predicted to have 1,532 amino acids, deduced from mRNA isoform 1 (Bao et al. 1997). Molecular analyses of GSD III have been reported, mainly in Jewish, Japanese, Caucasian, and Italian populations (Shen and Chen 2002). Those studies revealed that the spectrum of $A G L$ mutations in GSD III patients depends on ethnic grouping. For example, specific mutations were prevalent in Jewish GSD III patients (Parvari et al. 1997) and in an isolated region such as the Faroe Islands (Santer et al. 2001) because of founder effect, while heterogeneous mutations were found in Japanese patients (Horinishi et al. 2002; Okubo et al. 1996, 1998, 1999, 2000a, b). In Caucasian and Italian populations a few mutations accounted for a quarter of GSD III patients, but the rest of the mutations were heterogeneous (Lucchiari et al. 2002a, b; Shen and Chen 2002). To date, reports on other ethnic groups have been limited, and molecular analysis on patients from Germany, Canada, Afghanistan, Iran, and Turkey has yet to be performed.

Here, we investigated GSD III patients from Germany, Canada, Afghanistan, Iran, and Turkey and identified nine mutations, including six novel ones.

\section{Materials and methods}

\section{Patients}

Nine GSD III patients from eight unrelated families were investigated. They were German (patients 1, 2, and 3), Canadian (patient 4), Afghan (patient 5), Iranian (patient 6), and Turkish (patients 7, 8, and 9). Patients 7 and 8 were siblings whose parents were first cousins. The parents of patient 6 were first cousins as well. All patients were confirmed as having deficient debranching enzyme activity in peripheral red blood cells by the method of Shin (1990) and had been diagnosed with GSD IIIa. The study was approved by local ethics committees and performed with the patients' and their families' informed consent.
DNA sequence analysis of the $A G L$ gene

Genomic DNA was isolated from peripheral blood leukocytes. The full coding exons, their relevant exonintron boundaries, and the $5^{\prime}$ - and $3^{\prime}$-flanking regions of the patients' $A G L$ gene were sequenced directly as has been described previously (Okubo et al. 2000b). The nucleotides of $A G L$ cDNA were numbered according to $A G L$ isoform 1 (GenBank accession no. NM_000642).

\section{Mutation analysis of the $A G L$ gene}

Mutations identified in patients were verified using restriction fragment length polymorphism (RFLP). A pair of primers (listed in Table 1) was used for the polymerase chain reaction (PCR), and each specific restriction endonuclease was added to digest the PCR products. Restriction digests were analyzed on a polyacrylamide gel. Fifty Caucasian, 55 Japanese and 50 Turkish control DNA samples were examined by RFLP in the same manner to eliminate the possibility that they were mere polymorphisms in controls. Unfortunately, control DNA samples from individuals of Afghan and Iranian decent were not available in this study.

Haplotype determination in the $A G L$ gene

Twenty-three polymorphic markers in the $A G L$ gene were genotyped in accordance with previous reports (Horinishi et al. 2000, 2002; Okubo et al. 2000b; Shen et al. 1997).

\section{Results}

We identified nine mutations, six novel and three previously reported ones, in eight affected families. Results are summarized in Table 2. Fourteen mutated alleles out of 16 in the patients' $A G L$ genes were revealed. Sequence electropherograms are shown in the electronic supplementary material (S1).

Patient 1, of German descent, had a G-to-A substitution at nucleotide 765 in exon 7, leading to the replacement of tryptophan by termination at codon 255 (W255X). RFLP analysis with $\mathrm{Hga}$ I showed patient 1 to be heterozygous for W255X (Fig. 1a). The other allele has yet to be identified, though all 35 exons, their relevant exon-intron boundaries, and the $5^{\prime}$ and 3 '-flanking regions were sequenced.

Patient 2, of German ancestry, was shown to be homozygous for a nonsense mutation. Sequencing 
Table 1 PCR primers using RFLP detection for $A G L$ mutations. Exon sequences are represented by uppercase letters and introns by lowercase letters. Mismatch nucleotides are underlined. $F$ forward, $R$ reverse

\begin{tabular}{|c|c|c|c|c|}
\hline Location & Mutation & PCR primer $\left(5^{\prime} \rightarrow 3^{\prime}\right)$ for RFLP detection & $\begin{array}{l}\text { Restriction } \\
\text { enzyme }\end{array}$ & Fragment size (bp) \\
\hline \multirow[t]{2}{*}{ Exon 7} & $765 \mathrm{G}>\mathrm{A}$ & $\begin{array}{l}\text { F: CTT GTG AAT TCT CCA CAC } \\
\text { TTA AAA CCT GCC TGG }\end{array}$ & \multirow[t]{2}{*}{$H g a \mathrm{I}$} & Normal: 84 \\
\hline & {$[\mathrm{W} 255 \mathrm{X}]$} & $\begin{array}{l}\text { R: TTT CCC TTC TGC AAC ATC } \\
\text { ACA GGA GAA } \underline{\text { GCG }}\end{array}$ & & Mutant: $62+22$ \\
\hline Intron 7 & $\mathrm{IVS7}+5 \mathrm{G}>\mathrm{A}$ & $\begin{array}{l}\text { F: CTT AGA CAG AGC ACT TTG GC } \\
\text { R: ttt agt gtg ata ctc ctc tgt aaa ta }\end{array}$ & Ssp I & $\begin{array}{l}\text { Normal:131 } \\
\text { Mutant: } 106+25\end{array}$ \\
\hline Exon 9 & 1019delA & $\begin{array}{l}\text { F: CGA GTA ACC AAG TC̄T GAT CC } \\
\text { R: ATC TAC AGT ACA GCC AAA CCG TCT GAA T }\end{array}$ & Eco RI & $\begin{array}{l}\text { Normal: } 52+29 \\
\text { Mutant: } 80\end{array}$ \\
\hline Exon 16 & 1859-69del 11-bp & $\begin{array}{l}\text { F: ctc ttc ctg gac ata aat aat } g \\
\text { R: aga aac cac tga aat ctg gac }\end{array}$ & Alu I & $\begin{array}{l}\text { Normal: } 567+163 \\
\text { Mutant: } 346+210+163\end{array}$ \\
\hline Exon 21 & $\begin{array}{l}2590 \mathrm{C}>\mathrm{T} \\
{[\mathrm{R} 864 \mathrm{X}]}\end{array}$ & $\begin{array}{l}\text { F: GAA TTT GAA AAC TTG TCT CCA G } \\
\text { R: GCA TTG TCA ACA GCT AGG CTG }\end{array}$ & $T a q \mathrm{I}$ & $\begin{array}{l}\text { Normal: } 201+62 \\
\text { Mutant:263 }\end{array}$ \\
\hline Intron 21 & $\mathrm{IVS} 21+1 \mathrm{G}>\mathrm{A}$ & $\begin{array}{l}\text { F: CAT CTG ACA CAA TTC AGT CC } \\
\text { R: ggt aaa ggg tat gag gta tgc }\end{array}$ & $M s l \mathrm{I}$ & $\begin{array}{l}\text { Normal: } 330+78 \\
\text { Mutant: } 240+90+78\end{array}$ \\
\hline Intron 21 & IVS21 + 5insA & $\begin{array}{l}\text { F: TCC TAT ATT AAA AAT TCC TTT TGC TTC tta } \\
\text { R: ctg ctt aat tca gtc tag tgg }\end{array}$ & $A f l \mathrm{II}$ & $\begin{array}{l}\text { Normal: } 70+27 \\
\text { Mutant: } 98\end{array}$ \\
\hline Exon 25 & 3202-3delTA & $\begin{array}{l}\text { F: TTT GTT CAG AAT GGT TCA ACC } \\
\text { R: ttt cct ata act } \mathrm{ttt} c t t \operatorname{ccg} \mathrm{c}\end{array}$ & Dde I & $\begin{array}{l}\text { Normal: } 243 \\
\text { Mutant: } 125+116\end{array}$ \\
\hline Exon 31 & $\begin{array}{l}3980 \mathrm{G}>\mathrm{A} \\
{[\mathrm{W} 1327 \mathrm{X}]}\end{array}$ & $\begin{array}{l}\text { F: AAG GCT ATA AAG GTC TCA TAT GAT GTC T } \\
\text { R: CCA GAT TTG GAT GCT TTT CAT }\end{array}$ & $X b a \mathrm{I}$ & $\begin{array}{l}\text { Normal: } 115 \\
\text { Mutant: } 89+26\end{array}$ \\
\hline
\end{tabular}

Table 2 AGL mutations and single nucleotide polymorphisms (SNPs) in patients with GSD III. Novel mutations are in bold type. ND not determined

\begin{tabular}{|c|c|c|c|c|c|c|c|c|}
\hline Patient & 1 & 2 & 3 & 4 & 5 & 6 & 7,8 & 9 \\
\hline Ethnic group & German & nGerman & nGerman & Caucasian & from CanadaAfghan & Iranian & Turkish & Turkish \\
\hline Mutation 1 & \multicolumn{5}{|c|}{ W255X R864X IVS $21+1 \mathrm{G}>$ A1019delA } & ГA1859-69 & pIVS7 + & AIVS21 + 5insA \\
\hline Mutation 2 & ND & $\mathrm{R} 864 \mathrm{X}$ & ND & W1327X & & \multicolumn{3}{|c|}{ 3202-3delTA1859-69del 11-bpIVS7 + 5G > AIVS21 + 5insA } \\
\hline \multicolumn{6}{|l|}{ Consanguinity } & Yes & Yes & \\
\hline \multicolumn{9}{|l|}{ Polymorphism } \\
\hline-10 in exon 3 & $3 g g$ & aa & aa & ag & gg & gg & aа & aa \\
\hline IVS3 +85 & $\mathrm{tt}$ & $\mathrm{tt}$ & $\mathrm{cc}$ & $\mathrm{cc}$ & $\mathrm{tt}$ & $\mathrm{tt}$ & $\mathrm{cc}$ & $\mathrm{cc}$ \\
\hline-2 in exon $4^{\prime}$ & cc & $\mathrm{tt}$ & ct & $\mathrm{cc}$ & $\mathrm{cc}$ & $\mathrm{cc}$ & $\mathrm{cc}$ & $\mathrm{cc}$ \\
\hline IVS4-122 & ND & $\mathrm{tt}$ & $\mathrm{tt}$ & $\mathrm{tt}$ & $\mathrm{tt}$ & ND & ND & $\mathrm{tt}$ \\
\hline IVS6-73 & gg & aa & aa & aa & gg & gg & aa & aa \\
\hline $298 \mathrm{~L}$ & $\mathrm{tt}$ & $\mathrm{tt}$ & $\mathrm{ct}$ & ct & $\mathrm{tt}$ & $\mathrm{tt}$ & ND & $\mathrm{cc}$ \\
\hline R387Q & $\mathrm{RR}$ & RR & RR & $\mathrm{RR}$ & $\mathrm{RR}$ & $\mathrm{RR}$ & ND & RR \\
\hline IVS12 + 74 & ND & $\mathrm{cc}$ & ct & $\mathrm{cc}$ & $\mathrm{cc}$ & $\mathrm{tt}$ & $\mathrm{cc}$ & $\mathrm{cc}$ \\
\hline IVS12-125 & ND & $\mathrm{tt}$ & $\mathrm{tt}$ & $\mathrm{tt}$ & $\mathrm{tt}$ & $\mathrm{tt}$ & ND & $\mathrm{tt}$ \\
\hline IVS12-44 & ga & aa & aa & aa & aa & aа & ND & aa \\
\hline IVS13-70 & ND & $\mathrm{cc}$ & $\mathrm{cg}$ & $\mathrm{cc}$ & $\mathrm{cc}$ & gg & ND & $\mathrm{cc}$ \\
\hline IVS16 + 8 & $\mathrm{cc}$ & $\mathrm{tt}$ & $\mathrm{ct}$ & $\mathrm{tt}$ & $\mathrm{tt}$ & $\mathrm{cc}$ & ND & $\mathrm{tt}$ \\
\hline IVS21 + 124 & ND & aa & ga & gg & ND & ND & gg & ND \\
\hline IVS22 + 11 & aa & aa & aa & gg & aa & aa & ND & ND \\
\hline IVS23-121 & gg & aa & aa & aa & aa & gg & ND & aa \\
\hline IVS23-21 & aa & $\mathrm{tt}$ & $\mathrm{tt}$ & $\mathrm{tt}$ & $\mathrm{tt}$ & aa & ND & $\mathrm{tt}$ \\
\hline P1067S & $\mathrm{cc}$ & $\mathrm{tt}$ & $\mathrm{ct}$ & $\mathrm{cc}$ & $\mathrm{tt}$ & $\mathrm{cc}$ & $\mathrm{cc}$ & $\mathrm{cc}$ \\
\hline G1115R & GG & GG & GR & GG & GG & GG & ND & GG \\
\hline $\mathrm{R} 1253 \mathrm{H}$ & RR & RR & RR & RR & $\mathrm{RR}$ & RR & RR & RR \\
\hline IVS29 + 45 & ND & gg & ag & gg & gg & gg & gg & gg \\
\hline IVS29 + 53 & ND & $\mathrm{tt}$ & at & $\mathrm{tt}$ & $\mathrm{tt}$ & $\mathrm{tt}$ & $\mathrm{tt}$ & $\mathrm{tt}$ \\
\hline E1343K & $\mathrm{EE}$ & $\mathrm{EE}$ & $\mathrm{EE}$ & EE & EE & EE & $\mathrm{EE}$ & $\mathrm{EE}$ \\
\hline IVS32-97 & aa & gg & gg & gg & gg & gg & gg & gg \\
\hline
\end{tabular}


Fig. 1 Mutational analysis for GSD III patients. PCR products after digestion with restriction endonucleases (listed in Table 1) were electrophoresed. $M$ DNA marker, $P 1-P 9$ patients $1-9$, $C$ control, F2, 3, 6 father of patient 2, 3, 6, M2,3,6 mother of patient $2,3,6$

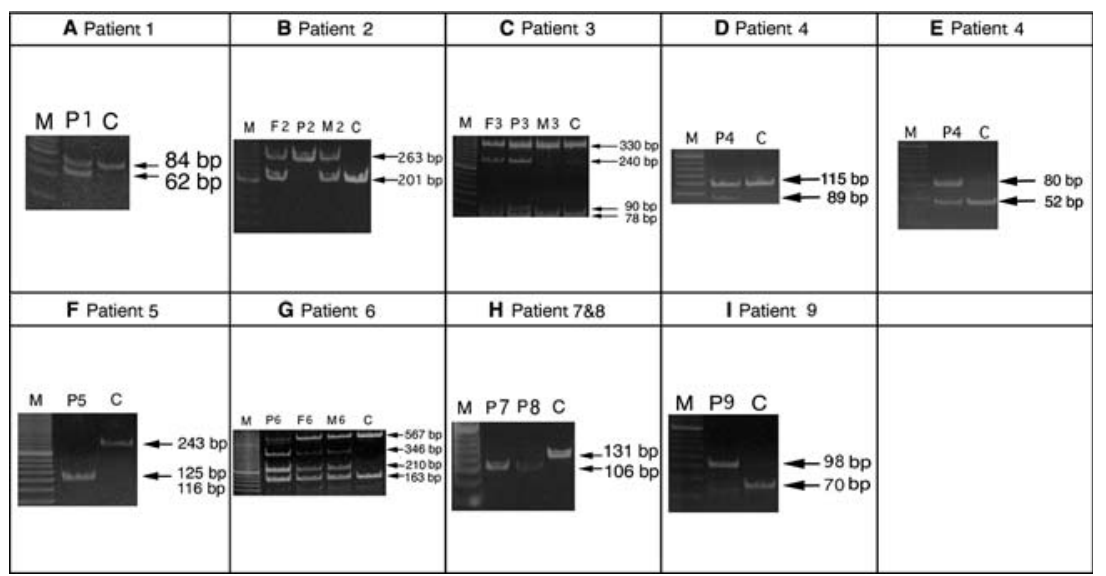

analysis showed a C-to- $\mathrm{T}$ transition at nucleotide 2590 in exon 21, resulting in substitution of arginine at codon 864 by termination (R864X). Restriction analysis with Taq I confirmed that patient 2 was a homozygote and that the parents were heterozygotes (Fig. 1b).

Patient 3 was heterozygous for a G-to-A substitution at +1 position of the donor splice site of intron 21 (IVS21 + 1G > A). Restriction analysis with $M s l$ I showed that patient 3 was heterozygous for IVS21 $+1 \mathrm{G}>\mathrm{A}$ as well as the father (Fig. 1c). The other allele has yet to be identified.

Patient 4, of Caucasian heritage from Canada, had a G-to-A substitution at nucleotide 3980 in exon 31, which replaces tryptophan by a termination at codon 1327 (W1327X). RFLP analysis with Xba I showed that patient 4 was heterozygous for W1327X (Fig. 1d). Further sequencing analysis revealed a deletion of A at nucleotide 1019 in exon 9 (1019delA), leading to a premature termination because of frame shift. RFLP analysis with Eco RI showed that patient 4 was a heterozygote for 1019delA (Fig. 1e). Thus, patient 4 was compound heterozygous for W1327X and 1019delA.

Patient 5, from Afghanistan, was homozygous for a 2-bp deletion in exon 25. Sequence analysis for patient 5 showed deletion of TA at nucleotides 3202 and 3203 , causing premature termination because of frame shift. RFLP analysis with Dde I verified that patient 5 was homozygous for the 2-bp deletion (Fig. 1f).

Patient 6, from Iran, had deletion of $11 \mathrm{bp}$ at nucleotides 1859-1869 in exon 16. RFLP analysis with $A l u$ I verified that patient 5 was homozygous for the $11 \mathrm{bp}$ deletion, while the parents were heterozygous (Fig. 1g).

Sequencing analysis of patients 7 and 8 , from a Turkish consanguineous family, revealed a G-to-A substitution at +5 position of the donor splice site of intron 7 (IVS7 + 5G > A). RFLP analysis using $S s p$ I showed homozygosity of the mutation in both patients (Fig. 1h).

Patient 9, of Turkish decent, was homozygous for a 1 bp insertion at +5 position of the donor splice site of intron 21 (IVS $21+5$ insA). RFLP analysis with $A f l$ II confirmed that patient 9 was a homozygote for the mutation (Fig. 1i).

These nine mutations were not found in 50 Caucasian and 55 Japanese control DNA samples. Neither of the splicing mutations found in the Turkish patients was detected in 50 Turkish controls.

Determination of single nucleotide polymorphisms (SNPs) in the $A G L$ gene showed that the three German patients had different $A G L$ haplotypes (Table 2). In patient 4 , the $A G L$ haplotype ( -10 in exon 3/IVS3 + 85/-2 in exon 4'/IVS4-122/IVS6-73/ 298L/R387Q/IVS12 + 74/IVS12-125/IVS12-44/IVS-70/ IVS16 + 8/IVS21 + 124/IVS22 + 11/IVS23-121/IVS2321/P1067S/G1115R/R1253H/IVS29 + 45/IVS29 + 53/ E1343K/IVS32-97) associated with W1327X was $(? / \mathrm{c} / \mathrm{c} /$ $\mathrm{t} / \mathrm{a} / ? / \mathrm{R} / \mathrm{c} / \mathrm{t} / \mathrm{a} / \mathrm{c} / \mathrm{t} / \mathrm{g} / \mathrm{g} / \mathrm{a} / \mathrm{t} / \mathrm{c} / \mathrm{G} / \mathrm{R} / \mathrm{g} / \mathrm{t} / \mathrm{E} / \mathrm{g}$ ) (?: we could not determine two SNPs in -10 in exon 3 and 298L, because DNA samples from the parents were not available for segregation analysis). We have described an Egyptian patient with the same W1327X elsewhere (Endo et al. 2005). The Egyptian patient had $(\mathrm{a} / \mathrm{c} / \mathrm{t} / \mathrm{t} / \mathrm{a} / \mathrm{c} / \mathrm{R} / \mathrm{c} / \mathrm{t} / \mathrm{a} / \mathrm{c} / \mathrm{t} / \mathrm{g} / \mathrm{g} / \mathrm{a} / \mathrm{t} / \mathrm{c} / \mathrm{G} / \mathrm{R} / \mathrm{g} / \mathrm{t} / \mathrm{E} / \mathrm{g})$, indicating that at least one SNP, i.e., -2 in exon $4^{\prime}$, was different from that of patient 4. Patients 5-9 were homozygous for SNPs, which we determined, although some SNPs were not examined because further DNAs were not available for genotyping.

\section{Discussion}

We have identified heterogeneous mutations in GSD III patients from ethnic groups in which no molecular 
studies have been reported. Of nine mutations identified in this study, six were novel and three had been previously reported. Novel mutations were one nonsense (W255X), three deletions (1019delA, 3202-3203delTA, and 1859-1869del11-bp), and two splicing mutations (IVS7 + 5G > A and IVS21 + 5insA). All nine mutations are predicted to lead to premature termination, which abolishes enzyme activity. Nonsense mutation $\mathrm{W} 255 \mathrm{X}$ is predicted to cause a truncated enzyme lacking the glycogen-binding site in the carboxyl terminal. Three deletions (1019delA, 3202-3203delTA, and 1859$1869 \mathrm{del} 11-\mathrm{bp})$ lead to a premature stop codon because of frame shift, resulting in truncated proteins as well. Alternatively, those premature termination codons will probably be recognized by nonsense-mediated decay, leading to absence of $A G L$ mRNA. Moreover, two mutations in donor splice sites (IVS7 $+5 \mathrm{G}>\mathrm{A}$ and IVS21 + 5insA) are likely to cause aberrant splicing, because no $A G L$ mRNA was detected in patients' peripheral leukocytes (data not shown). These results are consistent with the fact that the majority of the mutations reported are nonsense mutations, deletions, insertions, and splicing mutations (Shen and Chen 2002). Only six missense mutations have been reported thus far (Lucchiari et al. 2002b, 2003; Okubo et al. 1999).

Three mutations (R864X, IVS21 + 1G > A, and W1327X) have been previously reported in other ethnic groups. Nonsense mutation R864X in patient 2 has been shown to account for approximately $10 \%$ of the Caucasian GSD III mutant alleles in the United States of America (Shaiu et al. 2000; Shen et al. 1996). Splicing mutation IVS21 $+1 \mathrm{G}>\mathrm{A}$ in patient 3 from Germany has also been reported in Italian patients (Hadjigeorgiou et al. 1999; Lucchiari et al. 2002a, b) and a Japanese patient (Uotani et al. 2000). However, haplotype data have not been reported in the literature, and we could not compare ours with theirs. Presumably, $\quad$ IVS $21+1 \mathrm{G}>\mathrm{A}$ may be a recurrent mutation, but further $A G L$ haplotyping studies will be needed.

$\mathrm{W} 1327 \mathrm{X}$ is, to our knowledge, the third recurrent mutation reported in the $A G L$ gene. Two recurrent $A G L$ mutations have been verified by $A G L$ haplotyping. We demonstrated that splicing mutation IVS32$12 \mathrm{~A}>\mathrm{G}$ occurred in a Japanese patient and a Chinese patient, independently, by showing that they were on different haplotypes (Horinishi et al. 2002). Lam et al. reported that a Chinese patient and Faroese patients had the same nonsense mutation R408X on different haplotypes (Lam et al. 2004). As far as W1327X is concerned, Lucchiari et al. have described a Tunisian GSD III patient heterozygous for the mutation (Lucchiari et al. 2002a), but the haplotype has not been reported. Very recently, we identified an Egyptian patient homozygous for W1327X (Endo et al. 2005). In order to determine whether the mutation had occurred independently, we compared the $A G L$ haplotypes of two of the patients we studied. Patient 4 had a different haplotype from that of the Egyptian patient; the Canadian had $\mathrm{cc}$ in -2 in exon $4^{\prime}$, while the Egyptian had tt. Our finding indicates that $\mathrm{W} 1327 \mathrm{X}$ is the third recurrent mutation. Accordingly, $A G L$ haplotyping is useful to determine whether mutations are recurrent or not.

In summary, we have identified nine $A G L$ mutations, including six novel ones. Our molecular study on GSD III patients of different ethnic ancestry showed allelic heterogeneity of the $A G L$ mutations. This is the first $A G L$ mutation report for German, Canadian, Afghan, Iranian, and Turkish populations.

Acknowledgments This study was supported in part by Grantin-Aid for Scientific Research (C) \#13670856 from the Japan Society for the Promotion of Science, Grant-in-Aid for Young Scientists (B) \#18790743 from the Ministry of Education, Culture, Sports, Science and Technology, Japan, and a Research Grant from the Nakatomi Foundation.

\section{References}

Bao Y, Dawson TL Jr, Chen YT (1996) Human glycogen debranching enzyme gene (AGL): complete structural organization and characterization of the $5^{\prime}$ flanking region. Genomics 38:155-165

Bao Y, Yang BZ, Dawson TL Jr, Chen YT (1997) Isolation and nucleotide sequence of human liver glycogen debranching enzyme mRNA: identification of multiple tissue-specific isoforms. Gene 197:389-398

Chen YT (2001) Glycogen storage diseases. In: Scriver CR, Beaudet AL, Sly WS, Valle D (eds) The metabolic and molecular bases of inherited disease, 8th edn, vol I. McGraw-Hill, New York, pp 1521-1551

Endo Y, Fateen E, Aoyama Y, Horinishi A, Ebara T, Murase T, Shin YS, Okubo M (2005) Molecular characterization of Egyptian patients with glycogen storage disease type IIIa. J Hum Genet 50:538-542

Hadjigeorgiou GM, Comi GP, Bordoni A, Shen J, Chen YT, Salani S, Toscano A, Fortunato F, Lucchiari S, Bresolin N, Rodolico C, Piscaglia MG, Franceschina L, Papadimitriou A, Scarlato G (1999) Novel donor splice site mutations of AGL gene in glycogen storage disease type IIIa. J Inherit Metab Dis 22:762-763

Horinishi A, Murase T, Okubo M (2000) Novel intronic polymorphisms (IVS6-73A/G and IVS21 + 124A/G) in the glycogen-debranching enzyme (AGL) gene. Hum Mutat 16:279

Horinishi A, Okubo M, Tang NL, Hui J, To KF, Mabuchi T, Okada T, Mabuchi H, Murase T (2002) Mutational and haplotype analysis of AGL in patients with glycogen storage disease type III. J Hum Genet 47:55-59

Lam CW, Lee AT, Lam YY, Wong TW, Mak TW, Fung WC, Chan KC, Ho CS, Tong SF (2004) DNA-based subtyping of glycogen storage disease type III: mutation and haplotype analysis of the AGL gene in Chinese. Mol Genet Metab 83:271-275 
Lucchiari S, Donati MA, Parini R, Melis D, Gatti R, Bresolin N, Scarlato G, Comi GP (2002a) Molecular characterisation of GSD III subjects and identification of six novel mutations in AGL. Hum Mutat 20:480

Lucchiari S, Fogh I, Prelle A, Parini R, Bresolin N, Melis D, Fiori L, Scarlato G, Comi GP (2002b) Clinical and genetic variability of glycogen storage disease type IIIa: seven novel AGL gene mutations in the Mediterranean area. Am J Med Genet 109:183-190

Lucchiari S, Donati MA, Melis D, Filocamo M, Parini R, Bresolin N, Comi GP (2003) Mutational analysis of the AGL gene: five novel mutations in GSD III patients. Hum Mutat 22:337

Okubo M, Aoyama Y, Murase T (1996) A novel donor splice site mutation in the glycogen debranching enzyme gene is associated with glycogen storage disease type III. Biochem Biophys Res Commun 224:493-499

Okubo M, Horinishi A, Nakamura N, Aoyama Y, Hashimoto M, Endo Y, Murase T (1998) A novel point mutation in an acceptor splice site of intron 32 (IVS32 A-12 $\rightarrow$ G) but no exon 3 mutations in the glycogen debranching enzyme gene in a homozygous patient with glycogen storage disease type IIIb. Hum Genet 102:1-5

Okubo M, Kanda F, Horinishi A, Takahashi K, Okuda S, Chihara K, Murase T (1999) Glycogen storage disease type IIIa: first report of a causative missense mutation (G1448R) of the glycogen debranching enzyme gene found in a homozygous patient. Hum Mutat 14:542-543

Okubo M, Horinishi A, Suzuki Y, Murase T, Hayasaka K (2000a) Compound heterozygous patient with glycogen storage disease type III: identification of two novel AGL mutations, a donor splice site mutation of Chinese origin and a 1-bp deletion of Japanese origin. Am J Med Genet 93:211-214

Okubo M, Horinishi A, Takeuchi M, Suzuki Y, Sakura N, Hasegawa $\mathrm{Y}$, Igarashi $\mathrm{T}$, Goto $\mathrm{K}$, Tahara $\mathrm{H}$, Uchimoto $\mathrm{S}$, Omichi K, Kanno H, Hayasaka K, Murase T (2000b) Het- erogeneous mutations in the glycogen-debranching enzyme gene are responsible for glycogen storage disease type IIIa in Japan. Hum Genet 106:108-115

Parvari R, Moses S, Shen J, Hershkovitz E, Lerner A, Chen YT (1997) A single-base deletion in the $3^{\prime}$-coding region of glycogen-debranching enzyme is prevalent in glycogen storage disease type IIIA in a population of North African Jewish patients. Eur J Hum Genet 5:266-270

Santer R, Kinner M, Steuerwald U, Kjaergaard S, Skovby F, Simonsen H, Shaiu WL, Chen YT, Schneppenheim R, Schaub J (2001) Molecular genetic basis and prevalence of glycogen storage disease type IIIA in the Faroe Islands. Eur J Hum Genet 9:388-391

Shaiu WL, Kishnani PS, Shen J, Liu HM, Chen YT (2000) Genotype-phenotype correlation in two frequent mutations and mutation update in type III glycogen storage disease. Mol Genet Metab 69:16-23

Shen JJ, Chen YT (2002) Molecular characterization of glycogen storage disease type III. Curr Mol Med 2:167-175

Shen J, Bao Y, Liu HM, Lee P, Leonard JV, Chen YT (1996) Mutations in exon 3 of the glycogen debranching enzyme gene are associated with glycogen storage disease type III that is differentially expressed in liver and muscle. J Clin Invest 98:352-357

Shen J, Liu HM, Bao Y, Chen YT (1997) Polymorphic markers of the glycogen debranching enzyme gene allowing linkage analysis in families with glycogen storage disease type III. J Med Genet 34:34-38

Shin YS (1990) Diagnosis of glycogen storage disease. J Inherit Metab Dis 13:419-434

Uotani S, Yamasaki H, Takino $\mathrm{H}$, Kawasaki E, Matsuo $\mathrm{H}$, Yamasaki S, Jinno Y, Niikawa N, Ito M, Sugie H, Yamaguchi Y, Eguchi K (2000) Identification of a 5' splice junction mutation in the debranching enzyme gene in a Japanese patient with glycogen storage disease type IIIa. J Inherit Metab Dis 23:527-528 